\title{
Jak se mateřských škol dotýkaly transformační a kurikulární změny?
}

\author{
Soňa Kotátková \\ Univerzita Karlova v Praze, Pedagogická fakulta
}

Uplynulo více než dvacet letech od počátků transformace předškolního vzdělávání a pocituji, že se objevují nálady, které jsou u učitelek s dlouhodobou praxí podpořeny názory, že je potřeba se vrátit $\mathrm{k}$ některým osvědčeným praktikám z minulého způsobu práce (před rokem 1990). Jiné učitelky vyjadřují deziluzi, že jsou po době, kdy cítily možnost skutečně neformálně pracovat s dětmi podle jejich potřeb, vedeny k opisování klíčových kompetencí a konkretizovaných výstupů do svých prŕprav a např. pracovat ve všech tř́idách školy na jednom tématu, které určuje ŠVP bez ohledu na aktuální a více podnětné situace. Často se tyto odlišné názory objevují současně na jedné mateřské škole či v jedné tř́ídě. Jsou to podle mého mínění dost zásadní názorové diskrepance, které mohou ovlivňovat kvalitu soustředěného naplňování kurikulární reformy v předškolním vzdělávání. Co se to vlastně v průběhu téměř čtvrt století v předškolní výchově stalo? Ztratila se v poslední době možnost iniciativně a tvořivě uplatňovat pedagogickou práci? Jak se průběžně podílely transformační proměny a tlaky na fungování mateřských škol?

Pro pedagogy vyučující předškolní pedagogiku na pedagogických fakultách, kteří vývoj změn nemohli sami prožívat, nebo pouze krátkodobě či v lokálním rozměru, mohou být odpovědi na některé tyto otázky obtížné.

Transformační změny po roce 1990 i naplňování kurikulární reformy na jednotlivých stupních školy soustředěně sledují v posledních letech pedagogové v odborných příspěvcích, např. Greger (2011), Janík (2013), Janík, Maňák, Knecht a Němec (2010), Janík, Najvar a Solnička (2011), Kotásek (2009), Spilková (2012), Straková $(2007,2013)$ a jiní. Mateřské školy však stojí v těchto reflexích jaksi na okraji, lépe řečeno mimo ně. Změny probíhající v předškolním vzdělávání nebyly systematičtěji zaznamenány a analyzovány, nejsou k dispozici relevantní výzkumy, které by umožnily objektivní vhled do vývoje mateřských škol po roce 1990 . Ve svém diskusním př́íspěvku se chci zaměřit na změny v mateřských školách (dále také MŠ) v tomto období, k čemuž jsem zvolila strukturu čtyř fází transformačních změn podle Kotáska $(2005,2009)$, kterými jsou: 
(1) Dekonstrukce, která má časové určení 1990-1991 a je charakteristická vymezováním se (rozkladem) oproti stávajícímu stavu.

(2) Parciální stabilizace v časovém vymezení 1991-2000. Typická je přijímáním opatření k procesům, které je aktuálně třeba řešit, a analýzou stavu školství.

(3) Systémová rekonstrukce je určována léty 2001-2004. Zahájena je Národním programem rozvoje vzdělávání (2001) a následnou př́ípravou rámcových vzdělávacích programů.

(4) Implementace je Kotáskem vztahována do roku 2005 k přijetí školského zákona.

Výše uvedené časové a procesuální fáze transformace použiji $\mathrm{k}$ přiblížení změn v mateřských školách s jejich specifiky oproti ostatním stupňům vzdělávání a pokusím se některé z nich popsat a srovnat daný vývoj. Nabídnu svůj pohled na to, kam byly v uvedených fázích změny směřovány, kdy je možné je ještě brát jako součást nastoupené cesty v 90 . letech a na počátku milénia a kdy se již setkáváme s významnou změnou, kterou určuje společenské, politické a centralizované rozhodování, př́ípadně co ji způsobilo. V příspěvku uváděné postoje k vývoji mateřských škol vycházejí ze zdrojů (dotazníků a rozhovorů), které jsem dlouhodobě od počátku 90. let získávala a shromaždovala na seminářích dalšího vzdělávání učitelů (DVU) v pedagogických centrech na mnoha místech $v$ republice, později organizovaných pod záštitou Národního institutu vzdělávání pedagogických pracovníků (NIVPP), dále na vysokoškolských semináŕích DVU a u studentů kombinovaného studia na Pedagogické fakultě UK v Praze.

\section{Změny $\mathrm{v}$ mateřských školách $\mathrm{v} 90$. letech}

V tomto desetiletí převažují spontánní požadavky a volně realizované změny vycházející od učitelek a jednotlivých škol, které postupně začaly uplatňovat svoji autonomii. Tyto procesy se projevovaly jako hledání jiného způsobu práce, nebyly v ohnisku zájmu centrálních úřadů a jejich vývoj byl ve velké míře v režii jednotlivých škol. Můžeme upřesnit, že to byl proces zasahující všechny MŠ, avšak v různé míře. Velmi záleželo na osobní aktivitě jednotlivých učitelek či ředitelek. 


\subsection{Fáze dekonstrukce}

První fáze změny byla spojena s výraznými aktuálními iniciativami učitelek - „iniciativa zdola“, která měla více podob. Do konce ledna 1990 přišlo na adresu Občanského fóra (OF) učitelek MŠ 167 dopisů (některé vyjadřovaly názory za celou školu nebo za OF celého okresu) s kritikou a požadavky k současnému stavu. Kratochvílová (1989/90) uvádí některé návrhy učitelek:

(1) Žádaly snížení počtu dětí ve třídě na dvacet s argumenty, že 30-35-40 dětí vytváří neklidné a hlučné prostředí a „je příčinou neurotických poruch".

(2) Kritizovaly platy jako hluboce pod celostátním průměrem, poukazovaly na to, že odměny nejsou za „odvedenou práci a nabyté vzdělání“, vznášely požadavky na stejně dlouhou dovolenou jako v základních školách.

(3) Žádaly zrušit funkci inspektorek a mít k dispozici odborného poradce nebo psychologa.

(4) Navrhovaly jmenovat ředitelky na základě konkurzního řízení, snížit administrativu, inventarizaci a povinnost písemné př́pravy.

(5) Vyslovovaly zájem o vysokoškolské vzdělávání, protože jim chybí vzdělání v psychologii a speciální pedagogice a „nové poznatky o výchově a systémech předškolní výchovy ve vyspělých zemích".

(6) Ve vztahu k výchovně-vzdělávací práci si nejvíce stěžovaly na „závaznost normativních materiálů“. Zaznívalo zde také, že se „musí neustále přizpůsobovat př́kazům $\mathrm{z}$ vedoucích míst a pracovat $\mathrm{v}$ zaběhnutém stereotypu“.

(7) Učitelky vyslovovaly nespokojenost s nepružným fungováním Komenia (instituce zajišt'ující pomůcky pro všechny stupně škol) a s problémy při výběru vhodných hraček a pomůcek.

(8) Žádaly „přednostní zásobování potravinami - ovocem, zeleninou, jako podporu zdravé výživy“. (To souviselo s dlouhodobým nedostatkem různých druhů potravin.) (cit. podle Macháčkové, 2007, s. 104 -105).

Další významnou odbornou aktivitou byla porada pražských školních inspektorek, vedoucích Obvodních pedagogických středisek a mluvčích Občanského fóra v Praze (13. 2. 1990), která přinesla rozhodnutí, že Program výchovné práce pro jesle a mateřské školy (1984) budou učitelky používat jako otevřený 
materiál, jehož cílové požadavky zůstanou pro práci učitelek orientační. Bylo doporučeno, aby se upravil denní režim s větší tolerancí pro příchod a odchod dětí ze školy, „podporovat skupinovou práci, individuální péči a hravé formy práce“, prosazovat „celoživotní profesionální a kulturní rozvoj všech pedagogických pracovnic", a to při obvodních pedagogických střediscích (Minaříková, 1989/90, cit. podle Macháčkové, 2007, s. 105).

$\mathrm{Z}$ výše uvedených osmi požadavků byla většina splněna již v této fázi nebo na jejím přelomu, pouze platy, diferencované odměny např za vzdělání, spolupráce s psychologickým poradcem a zrušení inspekce splněno nebylo. Nastartování transformačního procesu mělo velmi silný potenciál, který byl provázen zásadní změnou v řídících pozicích, konkurzy na ředitelky MŠ proběhly v této fázi a znovu o tři roky později.

\subsection{Fáze parciální stabilizace v letech 1992-2000}

Zdola prosazovaná transformace pedagogické práce zdůrazňovala požadavky učitelek na větší ohleduplnost $\mathrm{k}$ dítěti, $\mathrm{k}$ jeho potřebám a individualitě. Rozhodnutí snížit počet dětí ve tř́ídách na čtyřiadvacet a postupný nástup slábnoucích populačních ročníků skutečně umožnily více se individuálně dětem věnovat.

Určitá vzdělávací cesta byla $\mathrm{v}$ tuto dobu čerpána $\mathrm{z}$ poznatků ze seminářů pořádaných při pronikání alternativních programů do mateřských škol Waldorfská mateřská škola (1992), Začít spolu (1994), Zdravá mateřská škola (1996), Montessori MŠ až na přelomu a v dalším tisíciletí. V průběhu devadesátých let přinesly alternativy první ukázky toho, jak jinak mohou vypadat programy pro výchovně-vzdělávací práci oproti předchozímu programu z osmdesátých let. Stále však byl po ruce Program práce pro jesle a mateřské školy (1984) a k němu vydané metodiky. Učitelky, kterým šlo o realizaci změn, začaly využívat možnosti spontánně a tvořivě reagovat na nové poznatky a také na podněty dětí.

Dostupnost MŠ byla dobrá, i když se v tomto desetiletí MŠ nebo tř́́dy v nich rušily. Jednak proto, že velmi poklesla porodnost, také se $\mathrm{v}$ polovině této fáze objevovaly politické kampaně (KDU-ČSL) zaměřené na to, aby děti byly vychovávány $\mathrm{v}$ rodinném prostředí, a MŠ nebyly prezentovány jako vhodné instituce pro výchovu dětí.

Správa a ř́zení mělo centralizovanou podobu, ale ministerstvo školství se o státní MŠ a způsob práce v nich nezajímalo a také pro veřejnost byly okra- 
jovou záležitostí. Na počátku roku 1995 byly MŠ vyzvány, aby si vytvořily samostatnou právní subjektivitu, která posílí jejich autonomii v oblasti manažerské, finanční a personální. Část škol toho využila, avšak některé ředitelky to vnímaly jako obtížné a právní subjektivitu pro svou školu nevytvořily. V některých regionech s osamostatňováním škol nesouhlasily školské úřady, a tak tyto školy zatím zůstaly pod státní správou. Na konci roku 2000 se však politickým rozhodnutím staly zřizovateli škol obce a po přelomu tisíciletí došlo z jejich podnětu na zásadní změny v řízení mateřských škol (viz 3. fáze).

Učitelky pocitovaly nízkou společenskou prestiž svého povolání. Stěžovaly si na rušení MŠ, pocitovaly nedostatečnost svého vzdělání. Finance pro školy i pro ohodnocení jejich práce byly nadále v této fázi označovány jako nedostatečné.

O vzdělávání měly učitelky velký zájem. Především to byly krátkodobé kurzy a semináře při pedagogických centrech, ale ucházely se také o studium na Pedagogické fakultě UK v Praze, která měla ve své nabídce vedle pětiletého magisterského studia oboru Pedagogika předškolního věku (otevřen od 1970 do 2005) i nový studijní program bakalářského studia Učitelství pro mateřské školy (od 1992/93). Od roku 1998 (do 2012) začaly být na této fakultě realizovány i různé formy dalšího vzdělávání pro učitelky mateřských škol. Podobné aktivity dalšího vzdělávání byly otevřeny i na jiných pedagogických fakultách, napřv v Centru dalšího vzdělávání na Pedagogické fakultě Ostravské univerzity (od roku 1991) se zaměřením na speciální pedagogiku pro učitelky mateřských škol (Burkovičová, 2010).

Integrace dětí se speciálními potřebami byla přijata se zájmem a snahou ji kvalitně realizovat.

Ke konci devadesátých let se však MŠ začaly vyhýbat přijímání dětí se zdravotním znevýhodněním, protože byly problémy s dofinancováním provozu při sníženém počtu dětí, na který měly při integraci nárok, a měl ho zajistit zřizovatel, tzn. obec/město.

Roli rodičů při společném působení na děti začaly učitelky chápat jako důležitou a hledaly způsoby spolupráce, někdy i velmi iniciativně. Rodiče však prŕliš nereagovali, udržovali určitý odstup a učitelky byly často zklamány a označovaly to jako malý zájem o děti. Učitelky i některé celé MŠ se ve spolupracujícím smyslu měnily rychleji než rodičovská veřejnost. 
Transformace MŠ probíhala v této fázi parciální stabilizace jako ústup od tradičního pojetí MŠ a postupné nastartování změny s převahou spontánního řešení vycházejícího zdola od učitelek na jednotlivých mateřských školách, bez opory veřejnosti, místní správy i nejvyšších řídicích orgánủ. Ke konci tohoto období volily učitelky a MŠ samy opatření k situacím, které se aktuálně objevovaly, byly ve své práci stabilizovány a orientovány více na potřeby dětí, na hledání možností individualizace i pedagogických metod odpovídajících dětským možnostem. Podpora centrálních úřadů a zřizovatelů byla nízká. Analýza funkce mateřských škol a jejich vzdělávacích činností nebyla prováděna, jak to tato fáze parciální stability předpokládá.

\section{Změny po roce 2000}

Významný přelom ve vzdělávání přinesl Národní program rozvoje vzdělávání v ČR - Bílá kniha (2001), který byl východiskem pro systémovou rekonstrukci školství. Formuloval základní cíle pro celý systém školního vzdělávání platný i pro mateřské školy, které byly oficiálně potvrzeny jako součást systému vzdělávání. Kromě rozvoje intelektových schopností zde bylo vyzdvihnuto také osvojování dalších dovedností a hodnot - duchovních, morálních, estetických a kvalitních vztahů v lidském společenství, výchova k partnerství a kooperaci. V souladu s těmito vzdělávacími principy byl zpracován i RVP PV. V Národním programu rozvoje vzdělávání byla také vyslovena doporučení týkající se posílení statusu profesionality učitele, a to i učitelů MŠ, kde základním doporučením bylo posunutí kvalifikace učitelů MŠ do terciálního vzdělávání na pedagogických fakultách. Doporučení je přímo formulováno ve smyslu utlumení vzdělávání na středních pedagogických školách a zrušení učitelské kvalifikace ze středoškolského studia (Kotásek et al., 2001). I když tato formulace podpořila postupný rozmach bakalářského oboru Učitelství pro mateřské školy na většině pedagogických fakult v ČR a tento stav trvá již deset let, přesto stále není zrušena kvalifikace pro pedagogickou práci v předškolním vzdělávání ze středních pedagogických škol.

\subsection{Fáze systémové rekonstrukce 2001-2005}

Mateřské školy měly po roce 2000 připravenou dobrou pozici pro další žádoucí rozvoj.

Směr zdola $v$ inovačních aktivitách učitelek procházel na počátku této fáze celkovým zklidněním. Většina MŠ již měla zažitý pocit určité autonomie. Za- 
tížení administrativou bylo poměrně nízké. Naplňování socio-kognitivních potřeb v práci s dětmi, které pocit’ovaly učitelky od počátku reformy, bylo podpořeno stále častějším zřizováním heterogenních tříd, což také vedlo $\mathrm{k}$ podpoře individualizace.

Pojetí kurikula školy, kde měly značnou autonomii učitelky jednotlivých tř́d, prošlo $\mathrm{v}$ předchozí fázi tápáním, ale ukazovalo se, že si učitelky začaly více věrit a iniciativně si vytvářet pracovní plány. $V$ prvních dvou letech po roce 2000 jsme si ověřovali v DVU, podle čeho vytvářejí učitelky své plány práce s dětmi, a zjistili jsme, že většina škol se již neuchyluje při své pedagogicképráci k Programu výchovné práce pro MŠ (1984), jak tomu bylo v předešlých letech. Sdělovaly, že si vytvořily ve své MŠ vlastní program. Hledaly a přebíraly různé náměty pro práci $\mathrm{z}$ metodických materiálů častěji vydávaných od poloviny devadesátých let, z alternativních programů a z praktických seminářu/dílen DVU při pedagogických centrech.

Nástup kurikulárních změn iniciovaných shora započal ověřováním RVP PV ve vybraných školách. V pedagogických centrech v ČR byly v roce 2004 realizovány semináře objasňující podstatu a následnou práci s RVP PV. Osobnostně orientovaný charakter výchovně-vzdělávacího působení zakotveného v tomto programu byl blízký směru dosavadní transformace mateřských škol. Vyjadřoval však jiné nároky na formulaci cílů i na vlastní pedagogickou práci, která měla vycházet $\mathrm{z}$ odlišné, $\mathrm{v}$ praxi nezažité struktury obsahu rozčleněného do pěti oblastí.

Dostupnost $M S ̌$ pro děti předškolního věku byla v této době velmi dobrá. Učitelky se obávaly dalšího poklesu zapsaných dětí, protože na přelomu tisíciletí byly naprosto nejnižší počty narozených dětí za celé dvacáté století. Školy se snažily získat děti z rodin všemi možnými způsoby. Nejvíce nabídkou zájmových kroužků (placených), často vedených nepedagogickými lektory, i když se hovořilo o tom, že tento způsob narušuje pedagogickou práci učitelek, které se tak dostávají na „vedlejší kolej“.

Správa škol prošla decentralizací, ze státní správy byla delegována na kraje a obce.

Řízení MŠ po roce 2001 se v mnoha školách v ČR změnilo. Zřizovatelé - obce začaly spojovat více MŠ pod jednu právní subjektivitu s jedním řízením. Znamená to, že jedna ředitelka/ředitel naplňovala svoji funkci pro více MŠ, např. i patnáct - všechny v daném městě - dále probíhalo slučování ZŠ s MŠ. 
Školy, které byly slučovány, neměly možnost jiné volby, nepomohly ani protesty rodičů. Situace stále trvá a jsou další místa, kde i v současnosti zřizovatel takto postupuje. Tento tlak shora je možné chápat jako silnou centralistickou intervenci, která nekompromisně zasahuje do přirozeného vývoje a fungování autonomie jednotlivých mateřských škol. Lze se zamýšlet nad tím, jestli je to pouze ekonomický důvod, že zřizovatel ušetří na platu několika ředitelek. Učitelky se spíše domnívají, že důvodem je lepší pozice zřizovatele při jednání $s$ jednou ředitelkou/ředitelem, než by tomu bylo $s$ více ředitelkami/řediteli. Zřizovatel tak může snadněji rozhodovat a prosazovat svoje požadavky.

Vzdělávání učitelek $\mathrm{v}$ průběžné formě bylo využíváno $\mathrm{v}$ bohaté síti pedagogických center $\mathrm{v}$ okresech, které v nabídce kurzů dokázaly reagovat na regionální potřeby škol a učitelek. Centra však byla na konci této fáze systémové rekonstrukce zrušena a pouze některá přešla pod NIVPP. Zaměření dalšího vzdělávání učitelů vycházelo z podnětů této centrální instituce a dojíždění do krajských měst ztížilo možnost účasti učitelek, např. z jedné MŠ. Zájem však byl stále intenzivní. Pedagogické fakulty začaly postupně otvírat bakalářský obor Učitelství pro mateřské školy. Přesto, že pracovně ani finančně učitelky nebyly (a nejsou) za vzdělání odměňovány, cítily ho jako oporu pro svoji pedagogickou práci (Kotátková, 2009).

Integrace dětí se speciálními potřebami prokazovala stagnaci až útlum ve tř́dách veřejných MŠ. Nedostatek financí, který nedovoloval snížení počtu dětí ve tř́dě, kde bylo dítě se speciálními potřebami, stále trval, zřizovatelé prakticky nepodporovali tento směr aktivity MŠ. Učitelky přestávaly mít o tuto práci zájem. Nebyla ohodnocena, nebyli asistenti pedagoga ani vhodná nabídka vzdělávání učitelek v tomto směru.

Problematika dětí ze sociokulturně znevýhodněného prostředí a podpora jejich přijímání do MŠ nebyla řešena na žádné úrovni od nejvyšších orgánů přes zřizovatele až k samotným mateřským školám. Přitom zřizovatelé mohli mít o tomto problému ve svém městě nejlepší přehled a zájem na jeho řešení. Otázky pokládané učitelkám $\mathrm{k}$ této problematice vedly $\mathrm{k}$ odtažitosti při odpovědích, a tím vyjadřovaly nezájem o tento zcela zásadní problém.

Děti jinojazyčné, jejichž počet se v tuto dobu zvyšoval, nebyl systémově řešen. Učitelky, kterých se týkala práce s těmito dětmi, se k ní stavěly intuitivně, bez podpory konkretizovaného vzdělávání, nabídky pomůcek a programů (tento stav stále trvá). 
Transformační procesy fáze systémové rekonstrukce, která přicházela s kurikulárním řešením vzdělávacího systému, byly ve svém počátku citlivě nastaveny $v$ návaznosti na procesy spontánního vývoje MŠ z 90. let. Ve zpětném analyzování větší šíře probíhajících procesů této fáze však můžeme konstatovat postupné svazování autonomie MŠ a opětné objevení se obav zásadněji se angažovat pro svoji nezávislost. Také se nepřipravila ani nerealizovala změna vysokoškolské kvalifikace pro učitelky MŠ. Centralizace dalšího vzdělávání učitelů do NIVPP rozbila sít' fungujících pedagogických center, která by při ponechání v původním rozsahu lépe prospěla př́ípravě MŠ na RVP PV, při vytváření ŠVP a následné implementaci kurikulární reformy. Mohlo být snazší aktuálně reagovat na regionální potřeby škol a učitelů. To jsou shrnuty některé součásti rubové strany této pozitivně nastavené fáze.

Výše zmíněné procesy změn na konci fáze systémové rekonstrukce jsou již, podle mého mínění, součástí implementace, která bude dále v tomto př́íspěvku přesahovat Kotáskem vytyčený rok 2005 směrem do současnosti.

\subsection{Fáze implementace (od roku 2005)}

Pokračování reformy produkovalo posilování tlaku shora. Na jednu stranu je to logické, když má mít reforma národní rozměr. Protikladem $\mathrm{k}$ tomuto faktu však byla nedostatečná opora centrálních institucí v počátcích implementace kurikulárních dokumentů v prvním stádiu 2004-2007. V druhém stádiu (2008-současnost) se neřešily konkrétnější potřeby pedagogických pracovníků při vzniklých problémech v začleňování kurikulárních předpokladů obsažených v RVP PV do podoby ŠVP a následně do pedagogické práce. Současně nebyly z nejvyšších míst podpořeny výzkumné aktivity ve státním rozměru, které by postihly vývoj a stav implementace kurikulární reformy (stále existoval VÚP v Praze).

V letech 2011-2013 se začaly objevovat zásahy do předškolního vzdělávání, které jako by zrcadlově naplňovaly tlak na změny v základním školství. Silným tématem byla snaha MŠMT začlenit závazné evaluační standardy pro výstup dětí z MŠ a následně upravit RVP PV. Změny, jež avizovalo MŠMT, nebyly s odbornou veřejností diskutovány. Petice, které byly na ministerstvo školství posílány a nesouhlasná stanoviska Asociace předškolní výchovy a pedagogických fakult, nebyly brány na zřetel. Až rezignace ministra částečně zmírnila dopad těchto změn na předškolní vzdělávání. Ministr Dobeš se $\mathrm{v}$ roce $2012 \mathrm{k}$ opatření, které prosazoval, vyslovoval tak, že nepůjde o selektování dětí podle výsledků z těchto testů, ale prověřování kvalit předškolního 
vzdělávání v jednotlivých MŠ. Je možné jen dodat, že si nelze představit, že by takto prověřované školy i nadále přijímaly děti, které by jim mohly „zkazit výkon", protože by je to přímo ohrožovalo. Soutěživost mezi školami by naprosto vytěsnila uznání dítěte s respektováním jeho individuálních zvláštností i nastoupený osobnostně orientovaný model předškolního vzdělávání.

V současnosti může implementaci kurikulárních dokumentů i nadále ovlivnit začlenění „ověřitelných standardů jako předpokladu zjištování kvality“, jak je předkládají Hlavní směry strategie vzdělávací politiky do roku 2020 (2013) nebo chystaný povinný poslední ročník mateřských škol v plánu současné vládní koalice. Za celých dvacet let transformačních proměn se právě v této etapě začal projevovat významný tlak nejvyšší centrální školské instituce.

Reagování na reformu zdola od učitelek mohlo naplnit předpoklad, že zažitá iniciativnost a zkušenosti z předchozích patnácti let podnítí autonomii učitelů při tvorbě ŠVP (2007) i následnou implementaci RVP PV do pedagogické práce. Ukázalo se však, že při vypracování ŠVP byla silná snaha vyhovět centrálním požadavkům a části textu RVP PV byly přepisovány bez zřejmého porozumění. Znovu se objevil jakýsi syndrom poslušnosti a obavy. Při snaze výkonnostně nasměrovat MŠ v letech 2011-2013 si učitelky (ředitelky) také jaksi nevěděly rady, na jakou stranu se mají přiklonit. Na to, že učitelky v mateřských školách jsou druhým početně nejsilnějším stavem pedagogických pracovníků v ČR, nebyla reakce na tyto změny odpovídající rozsahem ani porozuměním pro objevující se problém. Proč tomu tak bylo, těžko spekulovat.

Svoji roli mohly sehrát silné populační ročníky dětí v posledních šesti, sedmi letech a přeplněné tř́ídy mohly ovlivnit snížení iniciativy učitelek.

Kurikulum jako konkretizovaná vzdělávací cesta pro mateřskou školu s východiskem v RVP PV stěžejní pro tuto fázi se ukázalo pro ředitelky a učitelky jako obtížné i po předchozích zkušenostech. Přiklonila bych se k vysvětlení, že autonomie pedagogické práce nebyla ještě hlouběji zakotvena. RVP PV byl text, který si nedovedly představit v rovině konkrétních cílů, obsahu a metod vhodně zvolených pro podmínky jejich školy a potřeby dětí.

Průzkum v DVU na PedF UK u 53 učitelek z jednotlivých MŠ v letech 20072009 ukázal, že ŠVP připravily v jejich školách v 36 \% samy ředitelky, $21 \%$ ředitelky s vybranou učitelkou, ve $42 \%$ ředitelka s většinou učitelek a nebyla zvolena ani jedna varianta vypracování ŠVP se všemi učitelkami nebo i se zástupci nepedagogů. Při inovaci ŠVP po třech letech (2011/12) již vypovídalo 
25 učitelek, že ve většině případů se vytvářely změny ve ŠVP v týmové spolupráci všech učitelek. Inovace byly v těchto př́ípadech podpořeny vlastními zkušenostmi i větší sebedůvěrou pro volbu a zaměření obsahu i rozvržení pedagogické práce. Uvedený posun je možné interpretovat tak, že implementace kurikulárního dokumentu pro konkrétní podmínky mateřských škol a pro vlastní pedagogickou práci potřebuje čas, ale vedle toho i veřejnou pozitivní podporu, která se v této etapě nevyskytovala.

Dostupnost předškolního vzdělávání se výrazně zkomplikovala postupným populačním nárůstem dětí po roce 2005 , který vedl k masivnímu nepřijímání dětí do MŠ a zvýšení počtu dětí ve třídě, což naprosto změnilo možnosti individuální práce, která je základní myšlenkou osobnostně orientovaného modelu předškolního vzdělávání. MŠ se dále staly středem mediálního i společensko-politického tlaku v tom smyslu, aby byly přijímány děti již od dvou let bez vytvoření příslušných podmínek. Nedostatek míst v mateřských školách vedl k politickým opatřením typu „sousedská výpomoc“ - podnikatelský záměr pro péči o předškolní děti v jiných než vlastních rodinách, vznik firemních školek a v letošním roce schvalování tzv. dětských skupin. Všechna zmíněná řešení počítají s péčí o děti bez kvalifikovaných pracovníků a vzdělávacích programů. Výrazně se rozšírily placené instituce, např. soukromé mateřské školy, které nemusejí být v rejstř́ku škol MŠMT, a tudíž nemusejí podléhat předškolnímu vzdělávání ani jakékoliv evaluaci a supervizi ze strany ČŠI. Výrazná prezentace těchto MŠ podporuje představu rodičů o kvalitnějším fungování, kterou jim má zajistit finanční úplata. Významně se podpořil nárůst některých alternativ (opět rodiči hrazených), např. více jak o $100 \%$ se rozšírila od roku 2007 nabídka Montessori MŠ (center, klubů, tříd), z nichž značná část nemá v tomto směru vzdělané učitele. A v současné době i diskutované lesní kluby nebo třídy.

Správa a ř́zení se přiliš neodlišuje od předchozí fáze. Školy jsou materiálně slušně zabezpečeny, ovšem nejsou finance na odměny a jejich diferenciaci. V současnosti zřizovatel rozhoduje, zda bude vypsán konkurz na ředitelskou pozici, nebo jím bude potvrzena současná ředitelka/ředitel. Konkurzy mají často formální podobu a automaticky jsou potvrzovány stávající ředitelky. Úzká symbióza mezi zřizovatelem a vedením školy však nemusí být vždy ku prospěchu její kvality a může vytvářet rigidní vazbu.

Vzdělávání učitelek není v této fázi ani náznakem řešeno (ve smyslu Bílé knihy, 2001). Podmínka pro splnění adekvátní vysokoškolské kvalifikace učitelů 
mateřských škol nebyla otevřena ani $\mathrm{v}$ př́padě kauzy o vysokoškolské pedagogické kvalifikaci pro učitele ostatních stupňủ školy.Stále trvá dvoukolejnost v možnosti získání kvalifikace jak na středních pedagogických školách, tak na pedagogických fakultách. Ředitelky začínají být absolventkami vysokoškolského studia školského managementu, aniž absolvovaly příslušný bakalářský pedagogický obor nebo mají v základu pouze středoškolské vzdělání. $V$ praxi se pak často objevuje nesoulad mezi těmito ředitelkami a učitelkami, absolventkami pedagogického oboru učitelství pro mateřské školy na pedagogické fakultě. Problematické je to i s připravovanými standardy profese učitele (a kariérním systémem), které nepočítají s tím, že většina učitelek MŠ má středoškolské vzdělání.

Vysokoškolské vzdělávání nemá tedy oporu u nejvyššího ani u výkonného správního orgánu. Zřizovatel nepodporuje vzdělávání učitelek v kombinovaném vysokoškolském studiu např. časovou dotací na vzdělávání (učitelky si berou na studium dovolenou nebo musí veškerý čas věnovaný aktivnímu studiu napracovávat), ani možností finančních odměn pro absolventy s vysokoškolskou kvalifikací.

Integrace dětí se speciálními potrebami a inkluze je v pedagogických přístupech obtížně realizovatelná při vysokém počtu dětí (28) na jednu učitelku. Můžeme se domnívat, že v nejbližší době bude zapsaných dětí méně, ale panuje nejistota, zda se sníží i počty dětí ve trí́dách, nebo se budou třídy spíše zavírat a počet dětí v těch zbylých zůstane stejně vysoký. Dosažitelnost pedagogických asistentů se však mírně zvyšuje a pro učitelky MŠ se jeví lepší spolupráce se speciálně pedagogickými centry (SPC) než s pedagogicko-psychologickými poradnami (PPP).

Problematika dètí ze sociokulturně znevýhodněného prostředí a řešení jejich docházky do MŠ nejsou v tuto dobu silného nedostatku míst v mateřských školách ani zmiňovány, ani řešeny.

Fáze implementace není podle mého názoru zatím dokončena, stále probíhá implementace kurikulárního dokumentu RVP PV, která, jak se jeví její průběh, potřebuje čas a podporu veškeré odborné veřejnosti. Přes problémy, které se ukazují či pretrvávají, se vyvíjejí v pozitivních perspektivách, není důvod ji zpochybňovat, protože ji to oslabuje. Rodiče, kteří chtějí pro své děti kvalitní vzdělávání od předškolního věku, což ukazují zájmové aktivity, do kterých jsou děti přihlašovány, potřebují mít přístup $\mathrm{k}$ jasným a srozumitelným prezentacím vzdělávacích programů. Školy by je měly více otevřít pro rodiče dětí 
i danou obec a podporovat $\mathrm{v}$ nich komunitní soudržnost s občany a místními institucemi. Učitelky by měly na veřejnosti dokázat argumentovat ve prospěch ŠVP (i tř́ídních vzdělávacích programů) a zdůrazňovat, co konkrétního přinášejí pro děti. To je v jejich silách možné, mohou to udělat pro podporu a upevnění osobnostně orientované koncepce zakotvené v RVP PV.

\section{Závěr}

Závěrem se krátce zastavím u některých otázek položených v úvodní části tohoto diskusního příspěvku. Co se vlastně za čtvrtstoletí $v$ mateřských školách stalo? Není toho málo a převažují pozitiva. Pro pedagogickou práci a fungování školy máme př́íslušné legislativní a kurikulární dokumenty, ale o programu školy, třídy si rozhodujeme sami. Pluralita ve výběru programů předškolního vzdělávání je $\mathrm{v}$ mnoha směrech př́nosná pro rodiny i učitelky. $V$ žádném př́padě se neztratila možnost iniciativně a tvořivě pracovat $s$ dětmi, ale je nezbytné umět argumentovat pro volbu svých programových témat a zvolených metod, dokázat vysvětlit, proč třídní program bude mít určité odlišnosti. Př́nos současného pojetí spočívá v citlivosti pro potřeby dítěte, v podpoře individuálního rozvoje a kultivování jeho osobnosti, což je velký posun např. oproti šestému bodu požadavků učitelek z období 1989/1990.

Bez politických doporučení je možné studovat vhodné vysokoškolské obory pro učitele mateřských škol na všech pedagogických fakultách, i když to zatím příslušná místa neoceňují, ale je možné vycházet $\mathrm{z}$ vlastní sebereflexe, v souladu s potřebou se vzdělávat.

Jak se podílely transformační proměny a tlaky na fungování MŠ? Vybrané aspekty jsou v př́spěvku podrobněji popsány a snad zbývá dodat, že období uvolnění mělo svoji důležitost pro formování autonomie školy i učitele. Podle mého názoru bylo přínosné, že fázím systémové rekonstrukce a implementace předcházelo spontánní hledání možností, jak pracovat jinak, než tomu bylo $\mathrm{v}$ období direktivní správy a řízení mateřských škol a s tím souvisejících př́stupů ve výchově a vzdělávání v letech před rokem 1990. Kdyby byl program z osmdesátých let $\mathrm{v}$ krátké době po roce 1990 nahrazen jiným kurikulárním dokumentem, pak by se s největší pravděpodobností dalo předpokládat, že by iniciativnost a aktivita učitelek neproběhla a nový program by byl poslušně přijat a úzkostlivě naplňován tak, jak to bylo zvykem před rokem 1989. Změny, které spontaneitu (v některých př́ípadech však i nezájem učitelek) začaly výrazně ovlivňovat, přineslo období zavádění kurikulárních 
dokumentů do praxe. Tento krok reformy byl pro školní praxi v MŠ obtížný a „shora“ nebyl ani relevantně výzkumně sledován, ani podle potřeb škol dostatečně dlouho podporován. Nebylo a není možné odhadnout, jak ještě dlouho bude implementace této části reformy trvat a co se může ve školách objevit (formalismus, schematismus, stagnace). Jisté je, že za pět či sedm let nemůžeme program měnit a zásadně doplňovat jen proto, že zatím nevidíme u dané populace jakýsi očekávaný výsledek a z toho důvodu „předepsat změny" z pozice ministerstva.

Omezující zásahy přišly také v průběhu posledních deseti let především ze strany zřizovatelů při slučování MŠ, kde dochází k nerespektování nároků škol na vlastní autonomii, a to ve značném rozsahu. Smutné je také nepochopení funkce mateřských škol jako součásti vzdělávacího systému ze strany společensko-politické garnitury, které se projevilo v podpoře institucí, kde má jít pouze o hlídání dětí předškolního věku bez vzdělávacího programu, bez supervize evaluačního orgánu a s učiteli bez kvalifikace. $S$ tím bychom se určitě neměli smiřovat. Nemůže být na jedné straně u části populace vyžadováno plnění „konkretizovaných výstupů“ v systematické vzdělávací práci v MŠ a na druhé straně podpora pro instituce, kde se žádné vzdělávání nepředpokládá. To je v současnosti základní a nebezpečný rozpor. Některé učitelky to může vést $\mathrm{k}$ lhostejnosti a demotivaci ve smyslu, když se to nemusí plnit jinde, tak proč se snažit.

Pozice učitele $v$ mateřské škole - profesionála pro vzdělávání předškolních dětí však předpokládá, že zná a rozumí potřebám dětí i v didaktických souvislostech. Dokáže vycházet z příslušného vzdělávacího programu a promýšlet činnosti, které rozvíjejí celou dětskou osobnost. Součástí jeho pedagogického působení je i veřejně vysloveným názorem ochránit svoji práci před změnami, které by mohly předškolní dětství ohrožovat.

\section{Literatura}

Burkovičová, R. (2010). Učitelství pro mateřské školy. In V. Spilková \& H. Hejlová (Eds.), Př́íprava učitelů pro primární a preprimární vzdělávání v Česku a na Slovensku (s. 231-246). Praha: PedF UK v Praze.

Greger, D. (2011). Dvacet let českého školství optikou teorií změny vzdělávání v post socialistických zemích. Orbis scholae, 5(1), 9-22.

Hlavní směry strategie vzdělávací politiky do roku 2020 (2013). Praha: MŠMT. Dostupné z http:// www.vzdelavani2020.cz/clanek/12/aktualni-dokumenty.html

Janík, T., Maňák, J., Knecht, P., \& Němec, J. (2010). Proměny kurikula současné české školy: vize a realita. Orbis scholae, 4(3), 9-36. 
Janík, T. (2013). Od reformy kurikula k produktivní kultuře vyučování a učení. Pedagogická orientace, 23(5), 634-663.

Kotásek, J. (Ed.). (2001). Národní program rozvoje vzdělávání v ČR. Bílá kniha. Praha: ÚIV.

Kotásek, J. (2004). Budoucnost školy a vzdělávání. In E. Walterová, et al., Úloha školy v rozvoji vzdělanosti (s. 442-492). Brno: Paido.

Kotásek, J. (2009). Bílá kniha po pěti letech. Učitelské listy (18.11.2009). Dostupné z http:// www.ucitelske-listy.cz/2009/11/jiri-kotasek-bila-kniha-po-peti-letech.html

Kotátková, S. (2006). Směr vývoje současné mateřské školy. Pedagogická orientace, 16(1), 57-71.

Kotátková, S. (2009). Kvalita sociálního klimatu a potřeby učitelek mateřských škol. Studia paedagogica, 14(2), 69-84.

Kratochvílová, J. (1989/1990). Stav předškolní výchovy v Čechách a na Moravě. Zpravodaj mateřských škol, 6, 3-4.

Macháčková, I. (2007). Proměny předškolního vzdělávání a další vzdělávání učitelek mateřských škol v 90. letech 20. stol. In J. Kohnová \& I. Macháčková (Eds.), Další profesní vzdělávání učitelů a jeho perspektivy (s. 103-112). Praha: PedF UK v Praze a Ústav profesního rozvoje pracovníků ve školství.

Minaříková, M. (1989/90). Jak dále v Praze. Zpravodaj mateřských škol, 6, 1-2.

Opravilová, E., et al. (1993). Osobnostně orientovaný model předškolní výchovy. Závěrečná zpráva grantového úkolu MŠMT ČR - interní materiál. Praha: PedF UK v Praze.

Program výchovné práce pro jesle a mateřské školy (1984). Praha: SPN.

Rámcový vzdělávací program pro předškolní vzdělávání (2004). Praha: VúP.

Rýdl, K. (2004). Inovační procesy ve škole. In E. Walterová, et al., Úloha školy v rozvoji vzdělanosti (s. 304-315). Brno: Paido.

Spilková, V. (2012). Výzvy, které přináší osobnostně rozvíjející pojetí vzdělávání pro školu, učitele a vzdělávací politiku. In H. Lukášová (Ed.), Proměny pojetí vzdělávání a školního hodnocení. Filozofická východiska a pedagogické souvislosti (s. 41-70). Praha: Asociace waldorfských škol ČR.

Straková, J. (2007). Kurikulární reforma z pohledu šetření Kalibro. Pedagogika, 57(1), 21-36.

Straková, J. (2013). Jak dál s kurikulární reformou. Pedagogická orientace, 23(5), 734-743.

\section{Autorka}

doc. PaedDr. Soňa Kotátková, Ph.D., Univerzita Karlova v Praze, Pedagogická fakulta, Katedra primární pedagogika, M. Rettigové 4, 11639 Praha, e-mail: sona.kotatkova@pedf.cuni.cz 